that their names may be registered, and at the same time enclosing a remittance of one guinea, which will cover fifty telephone inquiries.

\section{Association of Women Science Teachers}

THE annual meeting of the Association of Women Science Teachers was held at Bedford College, London, on January 4 and 5. At the evening meeting, Prof. Allan Ferguson, lecturing on eighteenth century physics, stressed the value of the research of that century's Gargantuans in science, some interesting points of detail not always being known to presentday teachers. At the morning session, the Joint Standing Committee with the Association of Assistant Mistresses (Science Panel) presented its recent General Science Examination Syllabus, containing the maximum of content and topic for examination in general science after a five-year course to school certificate standard in girls' schools. Copies of this syllabus can be obtained on application to the Hon. General Secretary. A discussion was held on new methods of biology teaching, emphasizing practical problems with living organisms. Both plants and animals were discussed. It appeared there is less need for the keeping of animals in the school, except occasionally, when the biology is taught from the functional view-point and with reference specially to the mammal. Discussion ensued as to whether there may be consequent application or lack of it, in the pupil's mind, to man. The study of the characteristics of living things based upon exact observational work on plants and animals in school appears to present more practical difficulties in the keeping of living creatures in captivity. Opportunities for visiting a glass factory and a precious metals refinery were welcomed by members. It is announced that the Association proposes to devote a whole day's discussion on March 4, in London, to the Science Masters' Association General Science Report and to the Spens Report in its bearing upon science in the curriculum.

\section{Chinese Red Cross and Chinese Universities}

Mrs. HaLdane, who has recently returned to London after a visit to China, writes as follows: "I paid a visit to the training centre established by the Chinese Red Cross Medical Commission. This Centre is under the direction of Dr. Robert Lim, formerly professor of physiology in the National University of Peiping. Dr. Lim has temporarily given up his scientific work and has taken in charge the reorganization and extension of the Chinese Red Cross. . . . In Kunming, formerly known as Yunnan Fu, I had the pleasure of meeting President Chiang, formerly of the National University of Peiping, and his staff; and also President Mei of Tsing Hua University, Peiping, and his colleagues. - . Premises have been placed at the disposal of the universities by the Yunnan Provincial Government, but although they still have remnants of their former libraries, there is an almost complete dearth of equipment, scientific instruments and other material. The two Presidents and the professors of pure and applied engineering and biology informed me that they would be deeply grateful if their colleagues in Europe could send them copies of current periodicals, such as the Proceedings of the Royal Society, the Journal of Physiology and Biochemical Journal, physical and engineering journals, etc. If members of the various scientific societies in Great Britain would care to assist either the Chinese Red Cross Society, or Prof. Chiang and Prof. Mei and their staffs, I should be most grateful if they would communicate with me, c/o The China Campaign Committee, Parliament Mansions, Orchard Street, S.W.1. The Committee would be glad to make arrangements to forward either periodicals or money, and to put British scientific or university circles in touch with their Chinese colleagues who at present so badly need their moral encouragement and active assistance."

\section{Earth Tremor at Quetta}

ON January 6 at $4 \mathrm{~h}$. 43m. (Madras Time), an earth tremor of considerable intensity shook Quetta, in Baluchistan. The shock was of short duration and no damage or casualties are reported. It will be remembered that this district is liable to be visited fairly frequently by earthquakes and that it was visited by a particularly strong one on May 31, 1935, of duration about 30 seconds and having an epicentral tract 68 miles long and 16 miles wide in a direction S. $15^{\circ} \mathrm{W}$. from Baleli. The epicentre was stated by Sen and Bakshi to be lat. 30.5 N., long. $66.5^{\circ}$ E., and although the intensity was 10 on the Rossi-Forel scale, road and rail communications were not interrupted, nor was the supply of electric current, so that the intensity was not so great as at Assam in 1897, Kangar in 1905, or Bihar in 1934. No fault movement was apparent at the surface, and as the intensity fell off rapidly from the central region, the focal depth was assumed to be shallow. On that occasion, Kalat, Mastung, several villages and Quetta itself were completely destroyed, and Quetta was sealed for a considerable period owing to the extreme difficulty of the rescue work. The death roll was estimated at 15,000-20,000. The buildings of the new Quetta are of reinforced concrete and brick, and some attention has been paid to earthquakeproof design. They have withstood well the shocks of September and October 1937 and the present earthquake.

\section{Roads and Traffic}

IN his presidential address on "Roads and Traffic" to the Junior Institution of Engineers on December $\mathbf{9}$, Sir Charles Bressey raised many interesting questions the answers to which are not easily found out. $\mathrm{He}$ says, for example, that deductions from the most careful traffic observations are apt to be stultified, at any rate in a free country like Great Britain, by the essential fluidity and waywardness of traffic. The installation of traffic lights may lead drivers to make use of hitherto unfrequented side roads, so as to avoid the signals. These vagaries vitiate comparisons, and are particularly disconcerting in 
London, where so many alternative streets are available for an intelligent driver. In addition, the science of mechanical engineering advances so rapidly that steep road gradients which render a road unpopular at present may in ten years time offer practically no hindrance to a motor-car. Any attempt to replan an ancient capital must be largely empirical ; opportunism must play a leading part. The inertia of habit is a powerful force. Theoretical considerations have to be tempered by common sense based on a general knowledge of London's development and of the improvements which have been carried out or rejected during past years. However carefully the flow of traffic be recorded, we are still at a loss to account for the underlying causes of the waywardness. The mysterious flittings of trade and industry influence the distribution of the nation's population. The advantages of undeviating directness over great distances, unhesitatingly accepted by the Roman road engineers, who were untrammelled by county boundaries and ring fences around estates, would not be accepted implicitly to-day.

\section{Archæological Discoveries on Monte Alban, Mexico}

Excavatron of the Mixteco-Zapotecan necropolis on Monte Alban, near Oaxaca, Mexico, which has been in progress under the direction of Dr. Alfonso Caso without interruption since 1932, has produced a remarkable assemblage of objects, ornamental and ceremonial, in gold, semi-precious stone, or other material, illustrating the religion, life and customs of these peoples. In large measure the remarkable character of the finds justifies the dictum of the excavator that in the archæological sense this is the most important region in the whole of the Americas, not even excepting the Peruvian site of Cuzco. When one hundred and two tombs had been explored, the site was visited in the course of the past year by General L. Cardenas, President of the Republic. The occasion was marked by the opening of three further tombs, which the President, accompanied by Señor Caso, was the first to enter. The first tomb offered little calling for comment, but the second and third afforded the unexpectedly important and spectacular discovery of series of vivid polychrome frescoes adorning the walls. These depict gods and their symbols, as well as priests in ceremonial garb, sacred and mythological motives, and ritualistic symbols of life and death. In the third tomb, painted figurines were standing in ritual niches, and on the floor was a skeleton, obviously of a great chief, surrounded by a number of funerary objects, axes and knives in obsidian and flint, a green jade statuette of Quetzalcoatl, the Plumed Serpent of the Zapotecs, and a number of domestic and liturgical vessels. The mural decoration is considered to be the most important discovery yet made on Monte Alban. The President was so strongly impressed by the importance of the excavation that not only did he promise a Government subvention in order that the work might be continued, but also ordered an immediate grant of 10,000 piastres (approximately 60,000 francs). A brief account of the discovery and of the frescoes and contents of the tombs by Dr. Nuñez y Dominguez, secretary of the National Museum of Mexico, has recently appeared ( $J$. Soc. des Americanistes, N.S., $29,2)$.

\section{Insects of Cambridgeshire}

A LIMITED number of copies of the "Zoology of Cambridgeshire", the major part of which is occupied by the account of the Insecta, are now available. They are reprinted from the "Victoria County History of Cambridgeshire and the Isle of Ely", vol. 1, pp. 77-245 (1938), reviewed elsewhere in this issue (p. 46). Applications for these reprints, accompanied by a remittance of $£ 11 s$, which covers postage, should be made to the editor, Dr. A. D. Imms, Zoological Laboratory, Cambridge.

\section{Announcements}

DR. R. L. SмiтH-Rose has been appointed, as from January 1, superintendent of the Radio Department of the National Physical Laboratory, which includes the Radio Research Station at Slough in addition to the section of the Department at Teddington. Dr. Smith-Rose has been principal scientific officer-in-charge of the Departments ince Mr. Watson Watt left the Laboratory in 1936 to take up a position in the Air Ministry.

A BIBLIOGRAPHY on the housing and equipment of school libraries, compiled by Ellen L. Anderson, has been issued by the Office of Education, United States Department of the Interior. The bibliography consists of an annotated and selected list of references intended to show what schools have done for their libraries and to give concrete suggestions to those interested in starting a school library or in improving an old one. The list is limited to the physical aspects of the library and administration.

IN NATURE of December 24, p. 1130, in an article on "Future Developments in Coal Treatment and Utilization", reference was made to a paper by Prof. A. C. G. Egerton and to experimental work described by Mr. Armstrong. Mr. Armstrong was said to be a research student from South Africa. We are informed that this is incorrect; Mr. Armstrong is from New Zealand.

THE National Research Council of Canada, Ottawa, announces the forthcoming publication in book form of a scientific account of a comprehensive study on the effect of sulphur dioxide on vegetation. The book covers an investigation carried out under the auspices of the National Research Council during the period 1929-38 on the effect on vegetation in Northern Stevens County, Washington, of sulphur dioxide from the large metallurgical plant at Trail, B.C., and also elaborate experiments planned to elucidate the many questions which arose in connexion with the investigation.

Erratum.-NAture, January 7, p. 34, article entitled "Structure of Proteins", col. 2, paragraph 2, last line, for "marked" read "masked". 